\title{
Performance indices for pumping stations in irrigated rice fields
}

\section{Índices de desempenho para estações de bombeamento em lavouras de arroz irrigado}

\author{
Luciana Marini Köpp ${ }^{\mathrm{I}}$ Marcia Xavier Peiter ${ }^{\mathrm{II}}$ \\ Adroaldo Dias Robaina ${ }^{\text {II }}$ Leonita Beatriz Girardi ${ }^{\text {III }}$
}

\section{ABSTRACT}

Performance indices can be used as indices of energy use in irrigation systems. Pumping stations (PSs) are elements that require energy for irrigation of rice fields by conventional flood irrigation. Interplay of physical, hydraulic, and electrical parameters generates indices that determine the performance in the diagnosis of PSs, operation, and projects for new sets. In this study, it was proposed and classified performance indices for PSs in rice fields, focusing on the efficient use of energy. The study was carried out through an investigation of $160 \mathrm{PSS}$ in operation, located at the western border of Rio Grande do Sul, Brazil, which constituted an actual field situation. Next, PSs were optimized in relation to the selection of a piping system, using the lowest total cost, the choice of pump, and motors with better performance for the necessary situation as criteria. Results provided nine indices that classified the performance as "excellent", "very good", "good", "poor", and "very poor", which allowed the assessment of projects and the diagnosis of PSs.

Key words: energy efficiency, irrigation flooding, pumping systems, irrigation performance.

\section{RESUMO}

Índices de desempenho podem ser usados como indicadores do uso da energia em sistemas de irrigação. Estações de bombeamento (EB) são os elementos que demandam energia no processo de irrigação de lavouras de arroz irrigado por inundação convencional. A associação de grandezas fisicas, hidráulicas e elétricas geram índices que determinam o desempenho auxiliando no diagnóstico de EB, tanto em funcionamento, quanto em projetos de novos conjuntos. Este trabalhoteve como objetivo propor $e$ classificar indices de desempenho para EB de lavouras de arroz, com foco no uso eficiente da energia.O trabalho foi conduzido a partir do levantamento de dados de $160 \mathrm{~EB}$ em funcionamento, localizadas na fronteira oeste do Rio Grande do Sul, que caracterizou a situação real de campo. Posteriormente, as EB foram otimizadas em relação à seleção de tubulação- usando como critério o menor custo total e escolha da bomba e motor de melhor rendimento para a necessidade de projeto. Os resultados apresentam nove indices e propõem categorias que classificam o desempenho em "excelente", "muito bom", "bom”, "ruim” e "muito ruim”, permitindo a avaliação de projetos e o diagnóstico de $E B$.

Palavras-chave: eficiência energética, irrigação, inundação, sistemas de bombeamento, desempenho irrigação.

\section{INTRODUCTION}

The particular characteristics of pumping stations (PSs) in rice fields associated with the expanse of irrigated areas in Rio Grande do Sul (RS) when compared to other parts of Brazil, and the quantity of water and energy used in this process justify studies to optimize the use of these resources. Performance indices in irrigation areas are used to identify optimal sizing guidelines. ALEGRE et al. (2004) conceptualized a performance index as a quantitative measure of a particular aspect of performance of the managing entity or its service level. Thus, each index is a tool for monitoring efficiency (it measures the extent to which resources

'Departamento de Engenharia Rural (DER), Faculdade de Agronomia "Eliseu Maciel” (FAEM), Universidade Federal de Pelotas (UFPEL), 96010-610, Pelotas, RS, Brasil. E-mail: lucianakopp@gmail.com. Corresponding author.

"Departamento de Engenharia Rural (DER), Centro de Ciências Rurais (CCR), Universidade Federal de Santa Maria (UFSM), Santa Maria, RS, Brasil.

"I'Programa de Pós-graduação em Engenharia Agrícola (PPGEA), Centro de Ciências Rurais (CCR), Universidade Federal de Santa Maria (UFSM), Santa Maria, RS, Brasil. 
are optimally used for production) and effectiveness (it measures the extent to which management goals are met). DANTAS NETO \& FARIAS (2013) ranked performance indices by their relevance, selectivity, simplicity, low cost, comprehensiveness, stability, traceability, and reasonability. ROCAMORA et al. (2013) identified performance indices as tools for monitoring the quality of PSs.

OCACIA et al. (2002) studied PSs at rice fields on the western border of RS and established an index that relates the potential of a crop area and pumping height, and concluded that the most efficient PS should have a power consumption value of less than $30 \mathrm{~W} \mathrm{ha}{ }^{-1} \mathrm{~m}^{-1}$. However, values observed in the aforementioned study varied from $25 \mathrm{Wha}^{-1} \mathrm{~m}^{-1}$ to more than $100 \mathrm{~W} \mathrm{ha}{ }^{-1} \mathrm{~m}^{-1}$. CÓRCOLES et al. (2010) proposed the power used by a pumping volume unit $\left(\mathrm{kW} \mathrm{m}^{-3}\right)$ and active energy consumed $(\mathrm{kWh})$ as indices. This method was also used by DANTAS NETO \& FARIAS (2013), who suggested the use of indices that associate energy and power, as measured in the area covered by irrigation units and by the volume of pumped water $\left(\mathrm{kWh} \mathrm{ha}^{-1}, \mathrm{kWh} \mathrm{m}^{-3}, \mathrm{~kW}\right.$ $\left.\mathrm{ha}^{-1}, \mathrm{~kW} \mathrm{~m}^{-3}\right)$. The overall PS efficiency can serve as a performance index because it is determined by the parameters involved in the process (flow rate, geometric height, energy loss, and power demand). ABADIA et al. (2008) proposed a coefficient of global energy efficiency (GEE) that has two components: the efficiency of the equipment of a PS, and its spatial distribution, considering the water supplying distance, geometric height difference, and irrigation area. The current proposal aims to identify whether the cause of low efficiency is related to the equipment or its spatial distribution. The developed coefficient classifies PSs into categories (excellent, good, normal, acceptable, or unacceptable). The International Water Association (IWA) proposed a performance index associating the consumption of energy per unit volume of water pumped with a gauge height of $100 \mathrm{~m}$. This index is known as normalized energy consumption $\left(\mathrm{kWh} \mathrm{m}^{-3}(100 \mathrm{~m})^{-1}\right)$; allowing the comparison of PS performance at different heights (ALEGRE et al., 2004). The same authors proposed the use of normalized energy consumption to evaluate public supply systems, and recommended an approximate value of $0.5 \mathrm{kWh} \mathrm{m}^{-3}$ for every $100 \mathrm{~m}$ of gauge height.

The lack of reference values that could be used as decision-making criteria, considering the case of energy efficiency of one PS in a rice fields creates insecurity regarding the exchange, replacement or modification of items that make up the electromechanical system of water elevation in operation. The high investment values associated with special pricing tariff structures for irrigation (with reduced costs) do not encourage alterations necessary for optimizing a PS process. It is estimated that the installed power in rice fields in RS is approximately 500MW. Therefore, a lack of reference performance indices does not allow identification of the conditions of PSs in terms of efficient energy use. Considering this drawback, the goal of this research is to propose and classify performance indices (Pis) for water PSs used in the irrigation of rice fields; the developed method will allow the identification of sizing patterns to increase energy efficiency.

\section{MATERIALS AND METHODS}

The area of study included four municipalities on the western border of the state of RS. Total sample set included 45 properties with 160 PSs, of which 48 were located in Uruguaiana, 60 in Itaqui, 47 in Alegrete, and 5 in São Borja. Names of farmers were provided by the region's electric distribution company (AES SUL), which used as inclusion criteria the farmers' interest in participating in the Energy Efficiency Program (Programa de Eficientização Energética), developed by a company under the supervision of the National Electrical Energy Agency (Agencia Nacional de Energia Elétrica, ANEL).

Overall, the selected fields used flood irrigation with a water layer varying between 3 and $7 \mathrm{~cm}$, low wall systems, and an irrigation cycle between 80 and 100 days. PSs were triggered by electrical energy by using a tariff system, Horo-Sazonal green, and by adopting a restricted ordinance schedule.

Collection of field data included: a) Measurement of the geometric pumping height, suction of PS, and the respective piping lengths for total topographic station. b) Measurement of the flow rate by using a portable ultrasonic transit time flow meter. c) Measurement of electrical quantities: active power, voltage, and current, measured using a multimeter installed next to the electrical control board, with reading periods between 15 and $30 \mathrm{~min}$. d) Verification of the model and brand of the pump and motor, positioning of the pump and motor (horizontal or vertical axis), use of a floating structure, type of electric starter key, and piping material and its diameter.

Total gauge height of the PS analyzed was estimated from equation 1, which was adapted from the Hazen-William equation, and the hydraulic power derived from equation 2 . 


$$
\begin{aligned}
& \mathrm{TDH}=\mathrm{h}_{\mathrm{g}}+\left\{\left(\frac{\mathrm{Q}}{0.278 \times \mathrm{C} \times \mathrm{D}^{2.63}}\right)^{1.85} \times\left(\mathrm{L}+\mathrm{L}_{\text {vitual }}\right)\right\} \\
& \mathrm{P}_{\text {hyd }}=\frac{\gamma \times \mathrm{Q} \times \mathrm{TDH}}{1000} \text { (2) }
\end{aligned}
$$

where TDH is the total dynamic head $(\mathrm{m}), \mathrm{h}_{\mathrm{g}}$ is the geometric height $(\mathrm{m})$; $\mathrm{Q}$ is the measured flow rate $\left(\mathrm{m}^{3}\right.$ $\left.\mathrm{s}^{-1}\right), \mathrm{C}$ is the Hazen-Williams roughness coefficient (here we adopt a value of 90), $\mathrm{D}$ is the pipe diameter (m), L is the length of the pipe (m), $\mathrm{L}_{\text {virtual }}$ is the equivalent virtual length of the parts of the system (m), $\mathrm{P}_{\text {hyd }}$ is the hydraulic power $(\mathrm{kW})$, and $\gamma$ is the specific weight of the water $\left(\mathrm{N} \mathrm{m}^{-3}\right)$.

The overall efficiency of the system was estimated using the relationship between the hydraulic electrical power and the active power by using equation 3 .

$\eta_{\text {global }}=\frac{\mathrm{P}_{\text {hyd }}}{\mathrm{P}_{\text {active }}} \cdot 100$

where $P_{\text {active }}$ is the active power $(\mathrm{kW})$, and $\eta_{\text {global }}$ is the overall efficiency of the combination of all the pumping system equipment.

New projects were then developed based on the real data obtained in the field, aiming the reduction of energy use in the pumping water system. Physical conditions of the PS were not altered. Irrigation area, flow rate, geometric heights, and distances (piping length) were maintained. Piping diameter was adjusted to obtain the best option among standard options made of welded steel sheet. Criterion for selecting a suitable diameter was the least total cost over a period of 10 years of PS operation, based on the sum of fixed costs (piping) and operating costs (energy). After determining the optimal diameter, the TDH was reestimated using equation 1. The average PS operating time, obtained from energy bills made available by the farmers, was standardized at $1,800 \mathrm{~h}$ to allow comparisons of consumption rates.

Using the calculated TDH and the established flow rate of the project, the pump with the highest efficiency was selected for each of the 160 cases analyzed, among 68 preselected models (which are available for purchase). The motor was then selected using the required power as a criterion; high efficiency four-pole motors were selected. Thus, an optimized PS was obtained for the required pumping conditions, resulting in minimized energy consumption.

Nine performance indices were applied to the 160 PSs studied for the initial conditions (before) and for conditions in which the sets had been optimized through the substitution of piping, pumps, and motors adjusted for the recommended technical situation (after). The performance indices used are described in equations 4 to 11 .

$\mathrm{Pi}_{0}=\frac{\mathrm{P}_{\text {active }} / 1000}{\mathrm{~A} \times h_{\mathrm{o}}}$
$P i_{1}=\frac{P_{\text {active }}}{\mathrm{A}}(5)$

$\mathrm{Pi}_{2}=\frac{\mathrm{P}_{\text {active }} \times \Delta t}{\mathrm{~A}}$

$\mathrm{Pi}_{3}=\frac{\mathrm{P}_{\text {active }} \times \Delta t}{\mathrm{Vol}}(7)$

$\mathrm{Pi}_{4}=\frac{P_{\text {active }}}{Q \times T D H}(8)$

$P i_{5}=\frac{\widetilde{P}_{\text {nominal }}}{Q \times h_{g}}(9)$

$P i_{6}=\frac{P_{\text {nominal }}}{A \times h_{g}}(10)$

$P i_{7}=\frac{P_{\text {active }} \times \Delta t}{V o l \times T D H} \times 100$

where $\mathrm{Pi}_{\mathrm{O}}$ is a performance index $\left(\mathrm{W} \mathrm{ha}^{-1} \mathrm{~m}^{-1}\right), \mathrm{P}_{\text {active }}$ is the active power $(\mathrm{kW}), \mathrm{A}$ is the planted area supplied by the PS (ha), $\mathrm{h}_{\mathrm{g}}$ is the geometric pumping height (m), $\mathrm{Pi}_{1}$ is a performance index $\left(\mathrm{kW} \mathrm{ha}^{-1}\right), \mathrm{Pi}_{2}$ is a performance index $\left(\mathrm{kWh} \mathrm{ha}{ }^{-1}\right), \Delta \mathrm{t}$ is the duration of pumping $(\mathrm{h}), \mathrm{Pi}_{3}$ is a performance index $\left(\mathrm{kWh} \mathrm{m}^{3}\right)$, $\mathrm{Vol}$ is the volume of water pumped during the entire irrigation cycle, $\mathrm{Pi}_{4}$ is a performance index $\left(\mathrm{kW}\left(\mathrm{m}^{3} \mathrm{~s}^{-1}\right)^{-1} \mathrm{~m}^{-1}\right), \mathrm{Q}$ is the flow rate $\left(\mathrm{m}^{3}\right.$ $\left.\mathrm{s}^{-1}\right), \mathrm{TDH}$ is the total dynamic head $(\mathrm{m}), \mathrm{Pi}_{5}$ is a performance index $\left(\mathrm{kW}\left(\mathrm{m}^{3} \mathrm{~s}^{-1}\right)^{-1} \mathrm{~m}^{-1}\right), \mathrm{P}_{\text {nominal }}$ is the nominal power of the motor $(\mathrm{kW}), \mathrm{Pi}_{6}$ is a performance index $\left(\mathrm{W} \mathrm{ha}^{-1} \mathrm{~m}^{-1}\right)$, and $\mathrm{Pi}_{7}$ is a performance index $\left(\mathrm{kWh} \mathrm{m}^{-3}\left(100 \mathrm{~m}^{-1}\right)\right.$.

The indices defined above relate hydraulic, physical, and electrical parameters, thus allowing to identify the operational performance patterns of PSs. Categories of performance were proposed for each index studied, based on the results obtained before and after optimization of PSs (KÖPP, 2015). Categories were defined based on the amplitude of the values obtained, creating five equidistant classes, which are called "very poor", "poor", "good", "very good", and "excellent".

The relationship between the indices and the measures used for their determination (geometric height, irrigation area, unit flow rate, gauge height, overall production, and load loss) were tested using linear regression analysis.

\section{RESULTS AND DISCUSSION}

Results showed that optimization reduced the standard deviation and amplitude for every index, indicating that adjustments made in relation to the choice of piping, pumps, and motors led to a decrease 
in their variability. The variability that remained after the process is due to factors affecting the indices and those that were not altered, such as the unit flow rate (L $\mathrm{s}^{-1} \mathrm{ha}^{-1}$ ), geometric pumping height $(\mathrm{m})$, piping length $(\mathrm{m})$, and efficiency of the selected pump (\%),which was limited by options available in the market.

Comparing the $\mathrm{Pi}_{0}$ index "before" and "after" (see Table 1), it was observed that its value was adjusted by the process to less than $30 \mathrm{~W} \mathrm{ha}^{-1}$ $\mathrm{m}^{-1}$, as indicated by OCACIA et al. (2002) as the threshold for obtaining good performance. Regarding the $\mathrm{Pi}_{1}$ index, even the mean corresponding to the "before" condition (see Table 1) was lower than the value found by MARCOLIN \& ROBAINA (2002) of $0.684 \mathrm{~kW} \mathrm{ha}^{-1}$ in $31 \mathrm{PSs}$ in the central region of RS.

$\mathrm{Pi}_{2}$ and $\mathrm{Pi}_{3}$ indices, representing the consumption of PSs, with means of $798.83 \mathrm{kWh} \mathrm{ha}^{-1}$ and $0.064 \mathrm{kWh} \mathrm{m}^{-3}$ respectively, differed from the values obtained in other regions for different irrigation systems, such as those reported in MORENO et al. (2010) $\left(2,792 \mathrm{kWh} \mathrm{ha}^{-1}\right.$ and $\left.0.872 \mathrm{kWh} \mathrm{m}^{-3}\right)$, URRESTARAZU \& BURT (2012) $\left(0.16 \mathrm{kWh} \mathrm{m}^{-3}\right)$,

Table 1 - Mean values, standard deviations, minimum and maximum performance indices assessed in real operating conditions (before), and estimated for optimized configurations by the adaptation of piping, pumps, and motors (after) for the 160 pumping stations evaluated in the study in irrigated rice fields in RS.

\begin{tabular}{|c|c|c|c|c|c|}
\hline Index & unit & value & Before & After & Variation $(\%)$ \\
\hline $\mathrm{Pi}_{0}$ & $\mathrm{~W} \mathrm{ha} \mathrm{m}^{-1}$ & $\begin{array}{l}\text { mean } \\
\text { minimum } \\
\text { maximum }\end{array}$ & $\begin{array}{l}43.87 \pm 16.8 \\
14.81 \\
116.63\end{array}$ & $\begin{array}{l}27.59 \pm 5.5 \\
12.75 \\
57.98\end{array}$ & $37.11 \downarrow$ \\
\hline $\mathrm{Pi}_{1}$ & $\mathrm{~kW} \mathrm{ha-1}$ & $\begin{array}{l}\text { mean } \\
\text { minimum } \\
\text { maximum }\end{array}$ & $\begin{array}{l}0.444 \pm 0.206 \\
0.068 \\
1.676\end{array}$ & $\begin{array}{l}0.294 \pm 0.133 \\
0.054 \\
0.827\end{array}$ & $34.09 \downarrow$ \\
\hline $\mathrm{Pi}_{2}$ & $\mathrm{kWh} \mathrm{ha}^{-1}$ & $\begin{array}{l}\text { mean } \\
\text { minimum } \\
\text { maximum }\end{array}$ & $\begin{array}{l}798.83 \pm 371.31 \\
122.07 \\
3017.14\end{array}$ & $\begin{array}{l}529.74 \pm 239.81 \\
97.94 \\
1488.32\end{array}$ & $33.68 \downarrow$ \\
\hline $\mathrm{Pi}_{3}$ & $\mathrm{kWh} \mathrm{m}^{-3}$ & $\begin{array}{l}\text { mean } \\
\text { minimum } \\
\text { maximum }\end{array}$ & $\begin{array}{l}0.064 \pm 0.026 \\
0.064 \\
0.183\end{array}$ & $\begin{array}{l}0.043 \pm 0.020 \\
0.043 \\
0.108\end{array}$ & $32.60 \downarrow$ \\
\hline $\mathrm{Pi}_{4}$ & $\mathrm{~kW}\left(\mathrm{~m}^{3} \mathrm{~s}^{-1}\right)^{-1} \mathrm{~m}^{-1}$ & $\begin{array}{l}\text { mean } \\
\text { minimum } \\
\text { maximum }\end{array}$ & $\begin{array}{l}18.33 \pm 5.08 \\
11.10 \\
35.43\end{array}$ & $\begin{array}{l}13.06 \pm 0.68 \\
12.22 \\
16.30\end{array}$ & $28.75 \downarrow$ \\
\hline $\mathrm{Pi}_{5}{ }^{*}$ & $\mathrm{~kW}\left(\mathrm{~m}^{3} \mathrm{~s}^{-1}\right)^{-1} \mathrm{~m}^{-1}$ & $\begin{array}{l}\text { mean } \\
\text { minimum } \\
\text { maximum }\end{array}$ & $\begin{array}{l}26.48 \pm 10.66 \\
11.22 \\
72.68\end{array}$ & $\begin{array}{l}14.55 \pm 1.99 \\
9.95 \\
21.90\end{array}$ & $45.05 \downarrow$ \\
\hline $\mathrm{Pi}_{6}{ }^{*}$ & W ha ${ }^{-1} \mathrm{~m}^{-1}$ & $\begin{array}{l}\text { mean } \\
\text { minimum } \\
\text { maximum }\end{array}$ & $\begin{array}{l}47.01 \pm 23.65 \\
12.51 \\
181.28\end{array}$ & $\begin{array}{l}27.53 \pm 4.57 \\
12.51 \\
40.64\end{array}$ & $41.43 \downarrow$ \\
\hline $\mathrm{Pi}_{7}$ & $\mathrm{kWh} \mathrm{m}^{-3}(100 \mathrm{~m})^{-1}$ & $\begin{array}{l}\text { mean } \\
\text { minimum } \\
\text { maximum }\end{array}$ & $\begin{array}{l}0.509 \pm 0.141 \\
0.308 \\
0.984\end{array}$ & $\begin{array}{l}0.363 \pm 0.019 \\
0.340 \\
0.453\end{array}$ & $28.68 \downarrow$ \\
\hline$\eta_{\mathrm{g}}$ & $\%$ & $\begin{array}{l}\text { mean } \\
\text { minimum } \\
\text { maximum }\end{array}$ & $\begin{array}{l}57.39 \pm 14.60 \\
27.70 \\
88.37\end{array}$ & $\begin{array}{l}75.30 \pm 3.52 \\
60.18 \\
80.26\end{array}$ & $31.18 \uparrow$ \\
\hline
\end{tabular}

"based on nominal power. 
SOUZA et al. (2001) $\left(0.3 \mathrm{kWh} \mathrm{m}^{-3}\right.$ and $378.33 \mathrm{kWh}$ $\left.\mathrm{ha}^{-1}\right)$, and MEDEIROS et al. (2003) $\left(0.47 \mathrm{kWh} \mathrm{m}^{-3}\right.$ and $\left.4,401 \mathrm{kWh} \mathrm{ha}^{-1}\right)$. This result showed the great variability of these indices, which makes difficult to compare different conditions. This variability is associated with geometric heights typical of the area, the irrigation system used, and the type and size of pumps.

Although $\mathrm{Pi}_{4}$ and $\mathrm{Pi}_{5}$ indices are expressed in the same units of measurement, they represent different measures. $\mathrm{Pi}_{4}$ refers to the active power, whereas $\mathrm{Pi}_{5}$ indicates the nominal power of the motor. It follows that service factors smaller than one unit could lead to a higher $\mathrm{Pi}_{5}$ value than that obtained for active power. However, the determination of $\mathrm{Pi}_{5}$ is facilitated by the use of a power value indicated on the motor plate (motor's nominal power). Similarly, the height reference, used for deriving both indices, is different because $\mathrm{Pi}_{4}$ refers to the gauge height and $\mathrm{Id}_{5}$ refers to the geometric height, what is easy to obtain.

The $\mathrm{Pi}_{6}$ index was proposed because of the ease with which data requiring the nominal power of the motor, irrigated area, and geometric pumping height were obtained. This index and $\mathrm{Pi}_{5}$ were the indices with the greatest percentage variation between "before" and "after" (Table 1), according to the adjustment of nominal power that was carried out in relation to the active power.

The mean value for index $\mathrm{Pi}_{7}$ obtained after optimization was $0.363 \mathrm{kWh} \mathrm{m}^{-3}(100 \mathrm{~m})^{-1}$, which differed from that proposed by ALEGRE et al. (2004), who recommended a value of approximately $0.5 \mathrm{kWh}$ $\mathrm{m}^{-3}(100 \mathrm{~m})^{-1}$. The value obtained is due to the shorter piping lengths, when compared to those used in public supply services, on which the author's recommendations are based. This index shows a strong correlation with $\mathrm{Pi}_{4}$, although $\mathrm{Pi}_{4} \mathrm{t}$ differs in the measures used for its determination. Hence, both indices were retained, in spite of their similarities $\left(\mathrm{Pi}_{4}=\mathrm{Pi}_{7} \times 36\right)$.

The initial mean overall efficiency (before) was $57 \%$, a value that was slightly higher than that observed by ARNS (1995) (45\%), OCACIA et al. (2002) (47\%), and MOISES (2009) (50\%), caused by the improvement of installations over time. Process of optimization resulted in an increase of $31.2 \%$, thus reaching an average of $75 \%$, a value obtained based on the improved fit of the selected piping, choice of $t$ proper pump, and motor adjusted to the application. This value differs from that obtained by ABADIA et al. (2008); their study classifies levels of global production higher than $50 \%$ as "excellent". The variation reported between "before" and "after" shows the economic potential that can be obtained by the adaptation of PSs.

The partial result obtained when the effect of piping substitution alone was studied in relation to active power $(\mathrm{kW})$ showed a reduction of
$10.19 \%$, which led to the same reduction in energy consumption and costs. However, piping, pump, and motor replacement allowed an estimated reduction in active power consumption of $31.20 \%$.

The indices analyzed are related to each other and the measurements, as shown in table 2 . The $\mathrm{Pi}_{0}$ index is related to the unit flow rate $\left(\mathrm{q}\left(\mathrm{L} \mathrm{s}^{-1} \mathrm{ha}^{-1}\right)\right)$, where as $\mathrm{Pi}_{1}, \mathrm{Pi}_{2}$, and $\mathrm{Pi}_{3}$ indices are related to the geometric height. $\mathrm{Pi}_{4}$ and $\mathrm{Pi}_{7}$ indices, in contrast, are shown to be strictly dependent on the efficiency of the equipment. The relationships that were considered significant are presented in table 2 .

Table 3 shows the classification proposed for the nine performance indices presented in this study, indicating the range of values corresponding to"excellent", "very good", "good", "poor", and "very poor". It was suggested the use of the following indices: overall efficiency $\left(\eta_{\mathrm{g}}\right), \mathrm{Pi}_{4}$, and $\mathrm{Pi}_{7}$, in this order, to verify the performance of projects; $\mathrm{Pi}_{1}, \mathrm{Pi}_{2}$, and $\mathrm{Pi}_{3}$, in this order, to verify whether the location's topography is favorable for rice cultivation; $\mathrm{Pi}_{0}$, when comparing stations and identifying the energy consumption due to excessive water use in the irrigation process; and $\mathrm{Pi}_{5}$ and $\mathrm{Pi}_{6}$ indices, in case of difficulties in measuring active power or performing a quick estimate.

\section{CONCLUSION}

The combination of physical, hydraulic, and electrical parameters of PSs studied allowed the creation of indices that characterize performance in relation to energy consumption for water pumping in irrigated rice fields in RS. Using the overall cost minimization criterion, the choice of piping size, and more efficient pumps and motors resulted in a reduction of $31.20 \%$ in the energy consumption associated with the pumping process, relative to the configuration observed in the field for the 160 PSs studied.

Table 2 - Significant relationships between performance indices and hydraulic, electrical, and physical measures used in their determination for water pumping stations in irrigated rice fields in RS.

\begin{tabular}{llc}
\hline Relationships & \multicolumn{1}{c}{ Function } & $\mathrm{R}^{2}$ \\
\hline $\mathrm{Pi}_{0} f \mathrm{q}$ & $P i_{0}=16.1 \times q-3,0746$ & 0.6875 \\
$\mathrm{Pi}_{1} f \mathrm{~h}_{\mathrm{g}}$ & $P i_{1}=0.0246 \times h g+0.0271$ & 0.7805 \\
$\mathrm{Pi}_{2} f \mathrm{~h}_{\mathrm{g}}$ & $P i_{2}=44.363 \times h g+48.711$ & 0.7805 \\
$\mathrm{Pi}_{3} f \mathrm{~h}_{\mathrm{g}}$ & $P i_{3}=0,004 \times h g-0.00003$ & 0.9512 \\
$\mathrm{Pi}_{4} f \eta_{\text {global }}$ & $P i_{4}=-19.147 \times \eta_{\text {global }}+27.482$ & 0.9916 \\
$\mathrm{Pi}_{7} f \eta_{\text {global }}$ & $P i_{7}=-0.5319 \times \eta_{\text {global }}+0.7634$ & 0.9916 \\
\hline
\end{tabular}


Table 3 - Classification of performance indices for projects and analysis of water pumping stations for irrigated rice fields in RS.

\begin{tabular}{|c|c|c|c|c|c|}
\hline \multirow{2}{*}{ Index } & \multirow[b]{2}{*}{ excellent } & \multirow[b]{2}{*}{ very good } & \multirow{2}{*}{$\begin{array}{c}\text {-Categorie } \\
\text { good }\end{array}$} & \multirow[b]{2}{*}{ poor } & \multirow[b]{2}{*}{ very poor } \\
\hline & & & & & \\
\hline $\mathrm{Pi}_{0}\left(\mathrm{Wha}^{-1} \mathrm{~m}^{-1}\right)$ & $<20$ & $20 \vdash 30$ & $30-40$ & $40+50$ & $\geq 50$ \\
\hline $\mathrm{Pi}_{1}\left(\mathrm{~kW} \mathrm{ha}{ }^{-1}\right)$ & $<0.10$ & $0.10 \vdash 0.30$ & $0.30 \vdash 0.50$ & $0.50 \vdash 0.70$ & $\geq 0.70$ \\
\hline $\mathrm{Pi}_{2}\left(\mathrm{kWh} \mathrm{ha}^{-1}\right)$ & $<250$ & $250+550$ & $550 \vdash 750$ & 750 ト950 & $\geq 950$ \\
\hline $\mathrm{Pi}_{3}\left(\mathrm{kWh} \mathrm{m}^{-3}\right)$ & $<0.030$ & $0.030 \vdash 0.045$ & $0.045 \vdash 0.060$ & $0.060 \vdash 0.075$ & $\geq 0.075$ \\
\hline $\mathrm{Pi}_{4}\left(\mathrm{~kW}\left(\mathrm{~m}^{3} \mathrm{~s}^{-1}\right)^{-1} \mathrm{~m}^{-1}\right)$ & $<14.0$ & $14.0 \vdash 16.3$ & $16.3 \vdash 19.3$ & $19.3 \vdash 24.5$ & $\geq 24.5$ \\
\hline $\mathrm{Pi}_{5}{ }^{*}\left(\mathrm{~kW}\left(\mathrm{~m}^{3} \mathrm{~s}^{-1}\right)^{-1} \mathrm{~m}^{-1}\right)$ & $<14,5$ & $14.5 \vdash 19.5$ & $19.5 \vdash 24.5$ & $24.5 \vdash 29.5$ & $\geq 29.5$ \\
\hline $\mathrm{Pi}_{6}^{*}\left(\mathrm{~W} \mathrm{ha}{ }^{-1} \mathrm{~m}^{-1}\right)$ & $<22,1$ & $22.1 \vdash 33.1$ & $33.1 \vdash 44.2$ & $44.2 \vdash 55.2$ & $\geq 55.2$ \\
\hline $\mathrm{Pi}_{7}\left(\mathrm{kWh} \mathrm{m}^{-3}(100 \mathrm{~m})^{-1}\right)$ & $<0.389$ & 0.389 - 0.453 & $0.453 \vdash 0.536$ & $0.536+0.681$ & $\geq 0.681$ \\
\hline$\eta_{\mathrm{g}(\%)}$ & $\geq 70$ & $60 \vdash 70$ & $50 \vdash 60$ & $40 \vdash 50$ & $<40$ \\
\hline
\end{tabular}

*based on the nominal power of the motor.

For reference values of size or PS operation estimates, it was suggested the use of the following index values to achieve an acceptable index corresponding to a "good" rating: $\mathrm{Pi}_{0}<40 \mathrm{~W} \mathrm{ha} \mathrm{h}^{-1} \mathrm{~m}^{-1}$, $\mathrm{Pi}_{1}<0.50 \mathrm{~kW} \mathrm{ha}{ }^{-1}, \mathrm{Pi}_{2}<750 \mathrm{kWh} \mathrm{ha}{ }^{-1}, \mathrm{Pi}_{3}<0.060 \mathrm{kWh}$ $\mathrm{m}^{-3}, \mathrm{Pi}_{4}<19.3 \mathrm{~kW}\left(\mathrm{~m}^{3} \mathrm{~s}^{-1}\right)^{-1} \mathrm{~m}^{-1}, \mathrm{Pi}_{5}<24.5 \mathrm{~kW}\left(\mathrm{~m}^{3}\right.$ $\left.\mathrm{s}^{-1}\right)^{-1} \mathrm{~m}^{-1}$ (based on the nominal power of the motor), $\mathrm{Pi}_{6}<44.2 \mathrm{~W} \mathrm{ha}^{-1} \mathrm{~m}^{-1}$ (based on the nominal power of the motor), $\mathrm{Pi}_{7}<0.536 \mathrm{kWh} \mathrm{m}^{-3}(100 \mathrm{~m})^{-1}$, and $\eta_{\mathrm{g}}$ (overall efficiency) $>50 \%$.

\section{ACKNOWLEDGEMENTS}

The authors wish to thank the Conselho Nacional de Desenvolvimento Científico e Tecnológico (CNPq), Coordenação e Aperfeiçoamento de Pessoal de Nível Superior (CAPES) and AES Sul (electricity distribution company) by the opportunity obtaining data.

\section{REFERENCES}

ABADIA, R. et al. Energy efficiency in irrigation distribution networks I: theory. Biosystems Engineering, v.101, n.1, p.21-27, Sept. 2008. doi: 10.1016/j.biosystemseng.2008.05.013.

ARNS, R. Racionalização do uso de energia elétrica em bombeamentos de arrozais na Fronteira-Oeste do Rio Grande do Sul. Lavoura Arrozeira, v.48, n.418, p.14-17, Jan./Fev. 1995.

ALEGRE, $H$. et al. Indicadores de desempenho para serviços de abastecimento de água. Tradução e adaptação de Patricia Duarte, Helena Alegre e Jaime Melo Baptista. Lisboa: IWA/Lab. Nacional de Engenharia Civil/Inst. Regulador de águas e resíduos, 2004. 277p.

CÓRCOLES, J.I. etal. Management evaluation of WaterUses Associations using benchmarking techniques. Agriculture Water Management, v.98, n.1, p.1-11, Dez. 2010. doi: 10.1016/j.agwat.2010.07.018.

DANTAS NETO, J.; FARIAS, M. S. S. Indicadores de desempenho como instrumento de gestão em projetos de irrigação. In: AGUIAR NETO, A. O.; BASTOS, E. A. (Orgs.). Princípios agronômicos da irrigação. Brasília: EMBRAPA, 2013. p.219-262.
KÖPP, L. M. Índices de desempenho para estações de bombeamento em lavouras de arroz irrigado. 2015. 107f. Tese (Doutorado em Engenharia Agrícola) - Curso de Pós-graduação em Engenharia Agrícola, Universidade Federal de Santa Maria, RS.

MARCOLIN, E.; ROBAINA, A.D. Consumo de energia e eficiência das estações de bombeamento de lavouras de arroz irrigado. Ciência Rural, v.32, n.2, p.229-235, Apr, 2002.

MEDEIROS, S. de S. et al. Avaliação da eficiência do uso da energia elétrica no Perímetro Irrigado de Pirapora, MG. Revista Brasileira de Engenharia Agrícola e Ambiental, v.7, n.2, p.394-398, May/Aug, 2003. doi: $10.1590 / \mathrm{s} 1415-43662003000200035$.

MOISES, N. D. Energia elétrica para a irrigação do arroz na área da CELETRO. 2009. 92f. Dissertação (Mestrado em Energia, Ambiente e Materiais) - Universidade Luterana do Brasil, Canoas, RS.

MORENO, M.A. et al. Energy analysis of pressurised irrigation delivery systems: monitoring and evaluation of proposed measures for improving energy efficiency. Irrigation Science, v.28, n.5, p.445-460, Fev. 2010. doi: 10.1007/s00271-010-0206-8.

OCACIA, G.C. et al. Uso racional de energia em estações de bombeamento de água para irrigação de arroz. In: ENCONTRO DE ENERGIA NO MEIO RURAL, 4., 2002, Campinas, Proceedings on line... Available from: <http://www.proceedings.scielo.br/ scielo.php?script $=$ sci_arttext\&pid=MSC00000000220020002000 $63 \& \operatorname{lng}=$ en\&nrm $=$ abn $>$. Accessed: Jan. 12, 2015.

ROCAMORA, C. et al. Strategy for efficient energy management to solve energy problems in modernized irrigation: Analysis of the Spanish case. Irrigation Science, v.31, p.1139-1158, Oct. 2013. doi: 10.1007/s00271-012-0394-5.

SOUZA, G.H.F. et al. Desempenho do Distrito de Irrigação Senador Nilo Coelho. Revista Brasileira de Engenharia Agrícola e Ambiental, v.5, n.2,p.204-209. May/Aug. 2001. doi: 101590/s1415-43662001000200005

URRESTARAZU, L.P.; BURT, C.M. Characterization of pumps for irrigation in Central California: Potential energy savings. Journal of Irrigation and Drainage Engineering - ASCE, v.138, n.9, p.815-822. Sept. 2012. Available from: <http//dx.doi.org/10.1061/(ASCE)IR.19434774.0000463>. Acessed: Jan. 10, 2015. doi: 10.1061/(ASCE)IR.19434774.0000463 . 